\title{
Paul Piccone: Outside Academe
}

\author{
Russell Jacoby
}

"Do you think that, year after year, you will be able to stand seeing one mediocrity after another promoted over you and still not become embittered and dejected?"

The great German sociologist Max Weber put this question to those contemplating an academic career. He also answered it. In his experience, "very few" can witness these blows without suffering "inner damage."

That was 1919. Much has changed. Weber noted, for instance, that the university kept out Jews, and he said nothing of women. Today the academic world — open to Jews, women, and other previously excluded groups — has been completely revamped. Or has it? Despite the changes, is it possible the institution still promotes the mediocre and demotes the extraordinary?

The life and work of Paul Piccone bear on this question — and others. Piccone, who died of cancer in 2004 at 64, was a top-notch scholar, writer, and editor. A collection of his essays, Confronting the Crisis (Telos Press), has just been published.

Piccone and the university had parted ways long before his death. In 1987, Washington University in St. Louis turned him down for tenure. He had published a book with the University of California Press (Italian Marxism, 1983) that garnered a prize from the American Historical Association (the Howard R. Marraro Prize in Italian History); translated another book for a different university press, Enzo Paci's The Function of the Sciences and the Meaning of Man; and written several scholarly articles. He had enthusiastic letters of reference from luminaries like Daniel Bell and Jürgen Habermas. He edited a serious journal. No matter. He was too far outside the mainstream. He appealed the tenure decision and lost. Afterward, Piccone found occasional teaching positions but nothing secure or continuous.

Finally he gave up and moved to New York City with the journal he had founded, Telos. Piccone's path may be unique in American life and letters. Without family wealth, popular publications, or institutional backing, he remained a productive scholar who published a high-octane theoretical journal with no academic or foundation support for more than 30 years. Who has ever managed that? To say that he edited and published Telos barely captures Piccone's activities. He physically produced the magazine from his basement, preparing camera-ready pages and delivering them to the printer. To volunteer in the Telos office, or to be dragooned into volunteering, included hauling copies of each issue in a rented van from the printing press, sometimes hundreds of miles away, to the post-office loading dock.

Graduate students in philosophy at the State University of New York at Buffalo founded Telos. It emerged at a flashpoint of the 60s, in May 1968, and sought to break the stranglehold of a provincial Anglo-American philosophy. Translations and introductions to European thinkers and radicals filled the early issues. The Hungarian Marxist Georg Lukacs, the French critic Lucien Gold-mann, and Frankfurt School theorists such as Theodor Adorno and Herbert Marcuse jostled in its pages. For students like myself who had stumbled upon Telos, it was a full-time job keeping up. Each issue offered new faces. Who was this Italian phenomenologist, Enzo Paci? Who was the Vietnamese student of Maurice Merleau-Ponty, Tran Duc Thao? The Czech philosopher Karel Kosik?

Yet Telos — the magazine and Piccone became virtually interchangeable — never passively transcribed European thinkers. On the contrary. For better or worse, Piccone took seriously one obligation from Marxist thought, the charge to apprehend the current phase of history. He did this with a vengeance. He studded his writings with 
pronouncements of the failures of this or that writer to grasp the contemporary period. In the early issues, he took on Husserl and phenomenology. Then the Frankfurt School thinkers, followed by Habermas.

But with the "implosion" or self-destruction of the left by the 1980s, Piccone gobbled up new thinkers. He turned to ideas about community and populism as an alternative to what he saw as the intellectual bankruptcy of leftists - he thought too many leftists sought simply to expand the state. The idiosyncratic American historian Christopher Lasch captured Piccone's attention, as did conservative and libertarian thinkers who protested state bureaucracies. The right-wing — and for a time Nazi sympathizer — Carl Schmitt loomed larger and larger in the pages of Telos, which offered both translations and introductions to his work. In Schmitt, Piccone believed he had found an indispensable critic of liberalism and its failures.

Yet the demise of Piccone's academic career owed less to his intellectual peregrinations than to his social class or lack of class. Piccone came from solid Italian working people, butchers and tailors. He moved to Rochester, N.Y., with his family at the age of 14 . His father became a garment worker, making suits out of his house. Piccone noted that the first generation of Telos contributors consisted mainly of working- and lower-middle-class students able to attend graduate school because of higher education's vast expansion in the post-Sputnik years. Previously only "the eccentric offspring" of the rich had studied philosophy.

Piccone's background inoculated him against leftist clichés about the working class. "We knew the 'proletariat' all too well to harbor any illusions about its alleged emancipatory potential," Piccone wrote to explain Telos's uncompromising rejection of conventional Marxism. It may have also rendered him deaf to siren calls of the counterculture. Piccone, born in 1940, may have come of age in the 60s but seemed untouched by it, at least sartorially. I was a graduate student at the University of Rochester in the late $60 \mathrm{~s}$ when Piccone knocked on my door. We had talked on the telephone but never met. My jaw dropped when I saw him. I had never seen such a contemporary, at least not close up. He was clean shaven, with slicked-back hair, and wore a fine suit and polished, leather shoes. That was his everyday look.

Another leftist Italian-American of working-class origins coincidentally chaired my department at Rochester. Eugene Genovese, the historian of American slavery, also dressed to the nines. He once addressed us motley graduate students, mainly from New York City and its suburbs, as we clomped about in work boots, blue jeans, and work shirts: "You think the workers like what you are wearing?" he sneered. "They despise it and you." He fingered his own fine threads. "This is what they like. This is what they would wear if they could." Piccone would have agreed. They were right, of course.

Yet the issue went beyond suits. Piccone was an outsider who refused to knuckle under. If he dressed fine, he played rough. He ignored academic niceties. He did not know the meaning of deference. He would tell a friend as easily as a professional superior that a piece he or she had just written stank. Nor did he say it softly. Yet Piccone was not malicious. He was democratic to the core, slamming equally the high and the low. He once called the first issue of Telos not only "superfluous" but "inferior to the average" philosophical journal. He made no distinction between a new graduate student, a colleague, or a department chair. This is not the recommended path to tenure.

The writings collected in Confronting the Crisis offer a pale reflection of the man in full, and they omit some of his harder-hitting pieces (sometimes published under a pseudonym). Yet they display Piccone's tough-mindedness and his mix of footnotes and street talk. He called one book, for instance, George Katsiaficas's The Imagination of the New Left, a "disorganized collection of notes" that "recycled” ideas from "the Marxist conceptual junkyard." He was always summing up, settling accounts, and moving on. His mind worked like a band saw, slicing through material and throwing out what he called the "dead ends."

The pieces in this collection run from a scholarly overview of 19th-century Italian Hegelians to Piccone's later efforts to work out a "new" populism. Half the book deals with the failures of the left. For Piccone, leftists turned out to be bureaucrats, members of what he termed a "new class" that planned to expand the state. The new class constituted an educated elite devoted to employing itself and legislative solutions to everything. It stood for nothing more than a technocratic New Deal. Instead, Piccone looked for an new opposition among conservative thinkers linked to the so-called French New Right, such as Alain de Benoist, who sought to revitalize communitarian life.

To read Piccone is to gain an education; it is to follow an original, fearless thinker as he assesses the intellectual issues of the day. But he not only wrote bold essays, orchestrated translations, gave a platform to beginning scholars, and for three decades published a redoubtable journal. He also could set tile and pour concrete with the best of them. He once remarked that Telos probably stood alone among magazines in that its editor built its offices.

No one smacked less of mediocrity than Paul Piccone. A small man, he reached everywhere. That the university, 
which finds a place for so many, could find no place for him confirms Weber's warning. Yet in one respect Weber's admonition missed the target. Piccone never expressed bitterness. He knew life was unfair. Despite this, he led his with courage, verve, and often laughter. 
